\title{
Bilimkurgu Sinemasının Metinlerarasılık Bağlamında Analizi: Brazil Filmi Örneği
}

\author{
Analysis of Science Fiction Cinema in the Context of Intertextuality: \\ The Example of the Brazil Film
}

\author{
Semih SALMAN ${ }^{1}$
}

Öz

Bilimkurgu türü, sinemanın ilk dönemlerinden itibaren gelişme göstererek, pek çok sanat akımıyla etkileşim sağlamıştır. Bu sanat akımlarından biri de postmodernizmdir. Sinema alanında, 1980'ler sonrasında etkisini gösteren postmodernizm, çeşitli yaklaşımlar ve yöntemler geliştirilmesine olanak sağlamıştır. Bu yöntemler arasında olduğu bilinen metinlerarasılığın, sinemada ve diğer sanat dallarında belirgin bir biçimde tercih edildiği gözlenmiştir. Metinler arasındaki ilişkiyi ele alan bu yöntemin, bilimkurgu filmlerinde anlatı yapısının gücçlendirilmesini sağlayarak özgün bir dil yaratılmasında önemli bir unsur olarak dikkat çektiği görülmüştür. Çalışmada, sinemada bilimkurgu türünün gelişimi incelenerek, bu türün metinlerarasılık kavramıyla olan ilişkisinden hareketle Brazil filminin ayrıntılı bir biçimde analiz edilmesi amaçlanmaktadır. Nitel analizle ele alınan bu çalışma, fenomenoloji (olgubilim) desenine göre yapılandırılmıştır. Brazil'in, bilimkurgu türünün özelliklerini yansıtması, diğer filmlerle ve çeşitli sanat dallarıyla etkileşim kurması, çözümlemenin dayandığı temel nitelikleri oluşturmuştur. Elde edilen bulgulara göre, bilimkurgu sinemasında metinlerarası etkileşimden yararlanıldığı görülürken, çalışma kapsamında incelenen Brazil'de, kült filmlerin, edebi eserlerin, mitolojik kahramanların, dini ve siyasi konuları çağrıştıran ögelerin yer aldığı gözlenmiştir.

Anahtar Kelimeler: Bilimkurgu, Sinema, Metinlerarasılık, Brazil Filmi.

\begin{abstract}
The science fiction genre has developed since the early stages of cinema and interacted with many art movements. One of these art movements is postmodernism. Postmodernism in the field of cinema after the 1980s has enabled various approaches-methods to be developed. Intertextuality, which is known to be among these methods, is clearly observed in cinema and other branches of art. This method, which handles the relationship between texts, draws attention to important factors in creating an original language by strengthening the narrative structure in science fiction films. This study, it is aimed to analyze the film of Brazil in detail by examining the development of the science fiction genre in cinema, based on its relationship with intertextuality. This study, which is handled with qualitative analysis, is structured according to the phenomenology design. Brazil's reflection of the features of the science fiction genre and its interaction with other films and various branches of art have formed the basic qualities on which the analysis is based. As per research, besides the seen intertextual interaction in science fiction cinema, it was observed that cult films, literary works, mythological heroes, religious and political factors were in the study in Brazil.
\end{abstract}

Keywords: Science Fiction, Cinema, Intertextuality, Brazil Film.

Araștırma Makalesi (Research Article)

Gönderim Tarihi (Received):26.02.2021

Kabul Tarihi (Accepted):30.05.2021
Atıf (cite as): Salman, Semih. (2021). Bilimkurgu Sinemasının Metinlerarasılık Bağlamında Analizi: Brazıl Filmi Örneği, Akdeniz Üniversitesi Ileteișim Fakültesi Dergisi, 35, s. 299-316, DOI: $10.31123 /$ akil.887148

1 Dr. Öğr. Üyesi, İzmir Kavram Meslek Yükesekokulu-Görsel İşitsel Teknikler ve Medya Yapımcılığı Bölümü, semih.salman@kavram.edu.tr, ORCiD: 0000-0003-0872-1980 


\section{Giriș}

Sinema tarihinin ilk dönemlerinden itibaren yeni kavramlar, kuramlar ve teknikler geliştirilmiştir. Sinema alanında yaşanan bu gelişmelerde, sanat akımlarının ve teorik perspektiflerin etkili olduğu bilinmektedir. Bu bağlamda, sinemada popüler bir tür olarak kabul edilen bilimkurgunun temelinde, kuramsal yaklaşımların yer aldığını söylemek mümkündür. Sinemanın ilk dönemlerinde, George Méliès'in denemeleri, bilimkurgu türünün başlangıç evresini oluştururken, Das Cabinet des Dr. Caligari (Dr. Caligari'nin Muayenehanesi, Robert Wiene, 1920) ve Metropolis (Metropolis, Fritz Lang, 1927) filmlerinin de Alman dışavurumculuğunun ilk bilimkurgu örnekleri olduğu bilinmektedir. Estetik kaygıların ön plana çıktığı bu filmlerde, yönetmenler teknik unsurlardan ziyade kuramsal bir temele dayanarak bilimkurgu türünü ele almışlardır.

Bilimkurgu türünün gelişmesiyle birlikte, sanat alanında ortaya çıkan yeni akımlar da bu tür üzerinde etkisini göstermeye başlamıştır. Nitekim modernizm akımına tepki olarak ortaya çıkan postmodernizm kavramı, özellikle 1980'lerden itibaren sinemayla etkileşim içinde olmuştur (Büyükdüvenci ve Öztürk, 2014, s. 25). Bu çerçevede, bilimkurgu filmlerinde, postmodern yaklaşımı akla getirecek pek çok unsurun da yer aldığı görülmektedir. Distopik mekânlar, kaotik toplumlar, geçmişe öykünme, zamanda belirsizlik gibi ögeler, bilimkurgu sinemasında sıklıkla gösterilmektedir. Ayrıca, postmodernizmi temsil eden pek çok kavrama da (yapısökümü, metinlerarasılık, ironi, parodi, pastiş) bilimkurgu filmlerinde yer verilmektedir. Bu kavramlar arasında yer alan metinlerarasılık, bilimkurgu türüyle birlikte çalışmanın temelini oluşturmaktadır. Metinlerarasılık kavramının çeşitli sanat dallarıyla arasındaki ilişkiyi inceleyen Aktulum, "metinlerarası, postmodern yazının temel özelliklerinden biridir" saptamasına dikkat çekerek, postmodern yapıtlarda metinlerarası etkileşime sıklıkla yer verildiğini vurgulamaktadır (2000, s. 9-10). Jameson ise, postmodernizmde pek çok şeyin (gündelik yaşam, beden, politik temsiller) bir metin olarak sayılabildiğini ifade ederek, birbirinin üstüne yerleştirilen geniş metin gruplarının metinlerarası ilişkiyi temsil ettiğini belirtmektedir (1997, s. 76). Postmodern estetiği, dört kavrama (parodi/pastiş, prefabrikasyon, metinlerarasılık ve farklı parçaları birleştirip yeni bir şey ortaya çıkarma) dayandıran Hayward, tüm metinlerin başka metinlere gönderme yaparak metinlerarası ilişkiyi ortaya çıkardığına dikkat çeker (2001, s. 277-279).

Sinemada metinlerarasıı konusuna ilişkin belirli bir kuramsal sınıflandırma yapılmadığını belirten Aktulum, bu etkileşime yüzeysel yaklaşıldığını vurgulamaktadır (2018, s. 9-10). Sinema alanında metinlerarasılık yöntemi, filmin diğer filmlerle ve sanat dallarıyla olan ilişkisini ortaya koyarken, bu yaklaşımın bilimkurgu sinemasına belirgin bir biçimde etki ettiği düşünülmektedir. Hayward, tür filmlerinin kendi türünden olan diğer filmlere gönderme yaptığını ifade ederek, metinlerarası etkileşimin tür filmlerinde gerçekleştiğine dikkat çeker (2001, s. 171). Bu çerçevede, bilimkurgu türünde olan ve metinlerarası yaklaşımın özelliklerini yansıttığı düşünülen Brazil (Brezilya, Terry Gilliam, 1985) filmi, çalışmanın inceleme konusu olmuştur.

Çalışmada, sinemada bilimkurgu türünün gelişimi incelenerek, bu türün metinlerarasılık kavramıyla olan ilişkisinden hareketle Brazil filminin ayrıntılı bir biçimde analiz edilmesi amaçlanmaktadır. Nitel analiz yöntemlerinden biri olan fenomenoloji (olgubilim) deseninin kullanıldığı bu çalışmada, örneklem olarak Brazil filmi tercih edilmektedir. 


\section{Yöntem}

Çalışmada, sinemada bilimkurgu türünün gelişimi incelenerek, bu türün metinlerarasılık kavramıyla olan ilişkisinden hareketle Brazil filminin ayrıntılı bir biçimde analiz edilmesi amaçlanmaktadır. Nitel analizle ele alınan bu çalışma, fenomenoloji (olgubilim) desenine göre yapılandırılmıştır. Yıldırım ve Şimşek'e göre: "Fenomenoloji deseni farkında olduğumuz ancak derinlemesine ve ayrıntılı bir anlayışa sahip olmadığımız olgulara odaklanmaktadır” (2018, s. 69). Öte yandan, ayrıntılı film çözümlemesini içeren bu çalışmada "tematik film analizi" yönteminden de yararlanılmıştır.

Bu çalışmanın evreni, metinlerarası etkileşimi içeren bilimkurgu filmlerini kapsamaktadır. Bilimkurgu türünün hem sinemayla hem de diğer sanat dallarıyla etkileşim kurduğu düşünülerek, metinlerarasılık kavramının açık bir biçimde ifade edilebileceği öngörülmüştür. Çalışmanın örneklemini ise, bilimkurgu sinemasının kült filmlerinden biri olarak kabul edilen Brazil filmi oluşturmaktadır. Brazil'in, bilimkurgu türünün özelliklerini yansıtması, diğer filmlerle ve çeşitli sanat dallarıyla etkileşim kurması, çözümlemenin dayandığı temel nitelikleri oluşturmaktadır. Bu çerçevede, çalışmanın amacına uygun olduğu düşünülerek, amaçlı örnekleme yöntemi kullanılmaktadır. Amaçı örneklemenin mantığı ve gücü, derinlemesine çalışmak için bilgi açısından zengin durumların seçilmesinde yatmaktadır. Bilgi açısından zengin durumlar, araştırmanın amacı için merkezi öneme sahip konular hakkında çok şey öğrenilebilen durumlardır (Patton, 1990, s. 169). Nitekim amaçlı örneklemenin amacı, çalışılan konuyu aydınlatacak bilgi açısından zengin durumları seçmektir.

\section{Sinemada Bilimkurgu Türünün Gelișimi ve Distopik Kurgu}

Fransızca janr kelimesinden dilimize uyarlanan "tür" kavramı, sinemada çeşitli yaklaşımların yaratılmasına neden olmuştur. Bordwell ve Thompson (2008, s. 318), bu kavramın, filmlerin belirli tiplerini oluşturduğunu vurgulayarak, bilimkurgu, aksiyon, komedi, müzikal ve western gibi türlere dikkat çekerler. Tür, sinema izleyicisinin talep ettiği ürünleri ortaya çıkarır ve izleyicinin bu filmlerle ya da filmdeki karakterlerle özdeşleşmesini sağlar (Hunt, Marland ve Rawle, 2010, s. 84). Tür filmleri, anlaşılması kolay olan öyküleri içerir, somut olanı yansıtır ve tekrarlara dayanır (Abisel, 1995, s. 13). Bu filmler, tek bir alana hizmet etmekten ziyade birbirleriyle de ilişkili olabilirler. Hunt ve meslektaşları, türler arasında gezinen filmlerin daha başarılı olabileceğini öne sürerek, Star Wars (Yıldız Savaşları, George Lucas, 1977) filminin uzayda geçen bir Western, Blade Runner'ın da (Bıçak Sırtı, Ridley Scott, 1982), kara filmi temsil eden bir bilimkurgu ve gerilim türünü yansıttığını ifade ederler.

Sinemada popüler bir tür olarak öne çıkan bilimkurgu, bilinen veya hayâli bilimsel düşüncelere atıfta bulunularak kurgusal bir evren yaratılmasını içerir (Abrams, 1999, s. 278-279). Bilimkurgu, terim olarak, Hugo Gernsback'in kurduğu Science Wonder Stories dergisinin ilk sayısındaki sunuş yazısında ortaya çıkmıştır (Bauduo, 2005, s. 8). Mary Shelley'nin Frankenstein (1818) adlı romanı, bilinen ilk bilimkurgu romanıdır. Bu roman, sonrasında çekilen pek çok filmin ilham kaynağı olarak gösterilmektedir (Booker, 2010, s. xv). Bilimkurgu türünün, hayal gücünden destekle ve genellikle teknolojinin düşünsel deneyimiyle oluşturulduğunu belirten Roloff ve SeeBlen, edebiyat alanında önemli bir yeri olan Edgar Allan Poe'nun bilimkurgunun babası sayıldığını öne sürerler (1995, s. 34-127). Yazarlara göre bu durumun nedeni; Poe'nun The Pit and The Pendulum'da (Kuyu ve Sarkaç, 1843) olduğu gibi, bilimkurguyu akla getirecek ögeleri içeren pek çok roman ve öykü yazmış olmasından ziyade eserlerinde kapalı, özerk mikro dünyanın üretilmesi imkânını yaratmış olmasıdır. 
Bilimkurgunun, bilim ve teknoloji alanında yaşanan gelişmeler sonrasında, 19. Yüzyıl'da ortaya çıkan bir edebi tür olduğunu ifade eden Hayward (2001, s. 315), Jules Verne ve H.G. Wells'in, kendilerine özgü yaklaşımlarla bu türe katkıda bulunduklarını vurgular. Nitekim sinemanın başlangıç döneminde çektiği filmlerle dikkat çeken Fransız yönetmen George Méliès, J. Verne'in De la Terre à la Lune (Ay'a Seyahat, 1865) ve H.G. Wells'in The First Men in the Moon (Ay'daki İlk Insanlar, 1901) romanlarından yola çıkarak Le Voyage dans la lune (Ay'a Seyahat, 1902) adlı filmini ortaya çıkarmıştır (Reloff ve SeeBlen, 1995, s. 128). Sinemanın ilk dönemlerinde, dışavurumcu akımın örnekleri niteliğindeki Das Cabinet des Dr. Caligari ve Metropolis filmleri, bilimkurgu türünün önemli temsilcileri olarak öne çıkmıştır Özellikle Metropolis, hikâyesi ve kurgusuyla ilk bilimkurgu filmi olarak kabul edilmektedir. Ayrıca, Abel Gance'ın yönettiği La fin du monde (Dünyanın Sonu, 1931) ilk bilimkurgu afet filmi olarak bilinmektedir (Booker, 2010, s. xv-xvi).

1950’li yıllar bilimkurgu sinemasının tarihinde "altın çağ" olarak görülmektedir. Cornea, Amerikan yapımı bilimkurgu filmlerini ve özgün içerikli yapımları, yükselme evresinin nedeni olarak gösterir (2007, s. 30). Hayward da sessiz dönemde az sayıda bilimkurgu filmi yapıldığını belirterek, bu türün 1950’lerden sonra kendini gösterebildiğini ifade eder (2001, s. 315). Bilimkurgu filmleri, 1950 öncesinde insanlığı yok etme tehlikesini yaratan bilim üzerinden teknolojiye odaklanırken, 1950’li yıllardan sonra, dünyayı işgal etme eğiliminde olan uzaylı işgalcilere yönelmiştir. 1960'larda atom bombası ve nükleer savaş tehlikesi konularına ağırlık veren bilimkurgu filmleri dikkat çekerken, 1970’lerden itibaren söz konusu türün iyiden iyiye gelişme gösterdiği söylenebilir (Cornea, 2007, s. 112). Jaws (Denizin Dişleri, Steven Spielberg, 1975) filmiyle gişe rekorları kırılırken, ardından iki önemli bilimkurgu filmi; Star Wars ve Close Encounters of the Third Kind (Üçüncü Türden Yakınlaşmalar, Steven Spielberg, 1977) bu türün popüler hâle gelmesini sağlamışlardır. Nitekim söz konusu filmlerin devam serileri de daha sonraki yıllarda gösterime sunulmuştur.

Roloff ve SeeBlen (1995, s. 135), bilimkurgu sinemasında zamanla stereotipleşen kavramlara eleştirel bir perspektif çizerler. Zira bu türde, kendine özgü tipler yaratılarak kendi yasalarını belirleyen oyuncuların belirli şematik davranışları sergilediğini belirten yazarlar, kahramanların, belli fedakârlıklarda bulunma ve toplumsal dayanışmayı sağlama gibi aşamalarla çeşitli sınavlardan geçtiklerini vurgulamaktadırlar. Bilimkurgunun günümüze kadar pek çok aşamadan geçtiğini ifade eden Baudou (2005, s. 9-119), bu türün başka türlerle melezlendiğini iç içe geçtiğini öne sürer. Yazar, bilimkurguyu beş temaya ayırmaktadır: Uzay, zaman, makineler, başka dünyalar başka boyutlar ve dönüşüme uğramış insan. Uzay; uzay yolculuklarını, uzaylıları ve uzaylıların işgalini içerir. Star Trek (Uzay Yolu, 1966) serisi buna örnek olarak gösterilebilir. Zaman; geleceğe ve geçmişe yolculuk, postapokaliptik toplumları ele alır. Back to the Future (Geleceğe Dönüş, Robert Zemeckis, 1985), The Matrix (Matrix, Wachowski Brothers, 1999) filmleri zaman temasını akla getirmektedir. Makineler; yapay zekâ ve robotları işaret eder. A.I. Artificial Intelligence (Yapay Zekâ, Steven Spielberg, 2001) söz konusu temayı içeren bir filmdir. Başka dünyalar, başka boyutlar; paralel dünyalar, dördüncü boyut gibi konuları kapsar. Men in Black (Siyah Giyen Adamlar, Barry Sonnenfeld, 1997) filmi örnek olarak gösterilebilir. Dönüşüme uğramış insan; mutasyon geçirenleri, klonları, insan-makine karışımını içermektedir. The Terminator (Terminatör, James Cameron, 1984) filmi, bu temanın temsili niteliğindedir.

Bilimkurgu sinemasında, anlatı yapısını zenginleştiren birtakım kavramlar bulunmaktadır. $\mathrm{Bu}$ kavramlar arasında ütopya ve distopya, bilimkurgunun gelişmesinde ve genişlemesinde önemli bir rol oynamaktadır. Ütopya kavramı, politik ve sosyal açıdan ideal olanı temsil eder. Ancak böyle bir 
yaşam tarzı var olan dünyada mümkün görünmez (Abrams, 1999, s. 328). Bu kavram, Thomas More'un 1516 yılında yazdığı kitaptan türetilmiş ve mükemmel bir devleti tanımlamaktadır (Roloff ve SeeBlen, 1995, s. 91). Distopya ise, ütopyanın anti tezi niteliğini taşımaktadır ve kötü bir yer, korkulan bir dünya anlamına gelmektedir. Distopik hikâyeler, günümüz toplumlarındaki belli kusurların, doğal veya insan yapımı felaketlerin ardından yaşanılan yıkım sonrasındaki düzeni ele alır (Booker, 2010, s. 113). Bu kavramın ilk kullanımının 1868'li yıllara dayandığına dikkat çeken Vieira, John Stuart Mill'in parlamento konuşmasında, ütopyaya karşıt bir yaklaşımı nitelemek için distopya terimini kullandığını belirtmektedir (2011, s. 16). Sosyal ve politik düzenin teknolojinin etkisiyle olumsuz bir evren yaratması durumunu temsil eden distopya için, George Orwell'ın Nineteen Eighty-Four (Bin Dokuz Yüz Seksen Dört, 1949) adlı romanı örnek olarak gösterilebilir (Abrams, 1999, s. 328). Distopyanın toplumsal düzen hakkında bir eleştiri niteliği taşıdığını ifade eden Claeys, anti-ütopya veya negatif ütopya olarak da kullanılabilen bu kavramın, kaçınılması gereken yaşam tarzını yansıttığını vurgulamaktadır (2011, s. 107). Nitekim Claeys de bu türün en önemli temsilcisi olarak Nineteen Eighty-Fourromanını göstermektedir. Başlangıçta (özellikle Amerika Birleşik Devletleri'nde) teknolojik ilerlemenin sonuçlarıyla ilgili sinemada iyimser bir yaklaşımın görüldüğüne dikkat çeken Booker, özellikle son yıllarda bu tutumun değiştiğini ve distopik bir anlayışa doğru evrilme yaşandığını öne sürer. Ayrıca yazar, popüler sinemada distopik ruh hâlinin yükselişe geçtiğinin de altını çizer. A Clockwork Orange (Otomatik Portakal, Stanley Kubrick, 1971), The Handmaid's Tale (Damızlık Kızın Öyküsü, Volker Schlöndorff, 1990), Running Man (Ölüme Karşı Koşan, Paul Michael Glaser, 1987), THX 1138 (George Lucas, 1971) filmleri, bu türün popüler temsilcileri arasında yer almaktadır (Booker, 1994, s. 17-18).

İlk bilimkurgu filmi olarak bilinen Metropolis'in, distopik anlatı yapısına sahip olduğu görülmektedir. Kapitalist düzeni, işçilerin köleleştirilmelerini ve sanal bir makineye dönüşen toplumu anlatan bu film, o dönemlerde pek çok kişi tarafından ütopik olarak tanımlanabilecek teknolojik yeniliklere eleştirel bir yaklaşım getirerek, hikâyenin distopik türe yönelmesini sağlamıştır. Distopik türün, Hollywood endüstrisi dışında da tercih edildiği söylenebilir. Yeni Dalga akımının önemli temsilcilerinden biri olan Jean-Luc Godard'ın yönettiği Alphaville (1965), distopik kurguya sahip bir film olarak bilinmektedir. Uzak bir galakside geçen hikâyede, duygu ve yaratıcılıktan uzak Alfa 60 adlı bir bilgisayar, rasyonalist felsefeyle toplumu yönetmektedir. Godard, bilimkurgu türünde yaygın olarak görülen fütüristik anlayıştan uzak bir yaklaşım göstererek, filmde 1960'ların Paris sokaklarını ve o dönemin modasını yansıtmayı tercih etmiştir (Booker, 2010, s. 39). Ütopik anlatılarda, devletin halkı refah seviyesine çıkaracağı beklentisi yaratılırken, distopik kurguda ise, devlet toplumsal düzeni totaliter bir anlayışla elinde tutar. Distopik türdeki filmlerin anlatı yapılarında, zengin ve yoksul sınıf (özellikle işçi sınıfı) keskin bir şekilde ayrılırken, bu yaklaşıma sebep olan totaliter yönetim düzeni, militarist anlayışla varlığını sürdürür. Ayrıca distopik kurguda, teknolojinin insan yaşamına hükmederek duygusal yapıdan uzak, sert ve mükemmele yakın bir donanıma sahip olduğu vurgusu dikkat çeker.

Bilimkurgu türünün içinde çeşitli alt türler de bulunmaktadır. Alt tür; bir türün içinde belirli özelliklere sahip alt kategori olarak nitelendirilmektedir (Hunt vd., 2010, s. 84). Post-apokaliptik (postapocalyptic/kıyamet sonrası kurgusu) ve siberpunk (cyberpunk), bilimkurgunun içerisinde yer alan alt türler olarak bilinmektedir. Post-apokaliptik terimi, yeryüzündeki yaşamın sona ermesiyle birlikte insanların hayatta kalmasını konu edinmektedir. Post-apokaliptik kurgu, nükleer savaş, meteorlar, depremler, çevresel bozulmalar, veba ve elektromanyetik dalgalar gibi olası sorunların yaşanma ihtimali üzerinden biçimlenir (Curtis, 2010, s. 5-7). Siberpunk ise, bilgisayar veya bilgisayar ağları tarafından kontrol edilen insan veya yapay zekânın ana karakter olduğu, sanal gerçeklik içerisinde 
olayların gerçekleşmesini temsil eder (Abrams, 1999, s. 279).

Bilimkurgunun, diğer türlerle etkileşim kurarak anlatı yapısını daha da genişlettiği görülmektedir. Özellikle 1950'li yıllar sonrasında gelişme gösteren bilimkurgu türü, sinemanın ilk dönemlerinden günümüze kadar olan süreçte pek çok sanat akımını yansıtmıştır. Nitekim bunlar arasında dikkat çeken yaklaşımlardan biri de postmodern sanat akımını temsil eden metinlerarasılık yöntemidir. Şüphesiz bilimkurgunun hem sinemada hem de edebi türlerde belirgin bir biçimde öne çıkması, bu alanda metinlerarası etkileşimin kurulmasına imkân sağlamıştır.

\section{Sinemada Metinlerarası Etkileșim}

Postmodern yaklaşım, pek çok sanat alanında önemli bir unsur olarak dikkat çekmekle birlikte, çeşitli kavramların da gelişmesini sağlamıştır. Bu kavramlar arasında yer alan metinlerarasılık, 1960'larda Julia Kristeva tarafından ortaya çıkarılmıştır (Barthes, 1993, s. 126-127; Stam, 2000, s. 201; Allen, 2000, s. 14-15; Wiggins, 2019, s. 34; Hunt vd., 2010, s. 70). Mikhail Bakhtin'in türettiği söyleşimcilik kavramından hareketle metinlerarasılık yaklaşımını geliştirdiği bilinen Kristeva'nın, aynı zamanda dil bilimci Ferdinand de Saussure'un göstergebilim üzerine yaptığı çalışmalardan da etkilendiği belirtilmektedir (Allen, 2000, s. 14-15). Kristeva için metinlerarasılık; belirli bir metnin, bağımsız veya kapalı bir sistem olarak var olmadığı anlamına gelir (Kaminski, 2008 -den akt. Wiggins, 2019, s. 34). Kristeva, metinle diğer metinler arasındaki ilişkinin bu kavramı oluşturduğuna dikkat çekerek, metinlerin birbirlerine ilham verdiklerini ve bu bağlamda birbirilerini ürettiklerini öne sürer (Hunt vd., 2010, s. 70).

Pek çok kuramcı, metinlerarasılık kavramıyla ilgili çeşitli tanımlar geliştirmiştir. Göstergebilim alanında yaptığı çalışmalarla bilinen Roland Barthes, anlamın temelini işaret ederek, metnin, metinlerarası ilişkiden oluştuğunu anlatır (1993, s. 142). Leitch, metinlerarasılık yaklaşımının, dil ve metinsellik için sonsuz bir temelde oluştuğunu vurgulayarak bu kavramın paradoksal yapısının altında özgürleştirici bir determinizm sunduğunu ifade eder (akt. Hutcheon, 1998, s. 127). Fiske ise, metinlerarasılık yaklaşımının izleyici/okuyucu tarafından şekillendirildiğini, metinlerin daha geniş bir metinsellik ağında, parçalar olarak algılayan bir okuma oluşumu olduğunun altını çizer (Ott ve Walter, 2000, s. 429). Berger, tüm metinlerin farklı oranlarda diğer metinlerle ilişkili olduğunu belirtir (1995, s. 91). Yazar; bilinçli veya bilinçsiz bir biçimde başka metinlerden aktarma yapılması sonucunda da metinlerarasılık kavramının ortaya çıkabildiğine dikkat çeker. Herhangi bir metnin başka metinlerden etkilenmesi, etkileşim kurması anlamına gelen metinlerarasılık kavramının, taklit etmekten ziyade, anlamı farklı bir biçime dönüştürerek zenginlik kazandırdığı söylenebilir.

Metinlerarasılık kavramının ortaya çıkmasındaki temel unsurlardan biri olan "söyleşimcilik" kuramı Bakhtin tarafından geliştirilmiştir. Stam, söz konusu kuramın, sözcelerin arasındaki ilişkiyi vurguladığını belirterek, bu yaklaşıma göre, her metnin, metinsel yüzeylerin birleştirdiği noktaları biçimlendirdiğini ifade eder (2000, s. 201-202). Berger, Cultural Critism: A Primer of Key Concepts adlı kitabında Bakhtin'in ürettiği söyleşimcilik kuramını diyalojik (dialogical) teori olarak nitelerken, bu kavrama göre iki önemli unsur öne çıkarır. İlki, fikirlerimizi ve yarattıklarımızı etkileyen bir geçmişin varlığıdır. İkincisi, yaptığımız şeyi etkileyen izleyicilerimizden (gerçek veya hayali) beklediğimiz tepkiler ve bir geleceğin varlığıdır (1995, s. 35-36). Bakhtin, insanların iletişiminin tamamının diyalojik olduğunu savunarak, söylenen sözlerin süregelen bir diyaloğun unsuru olduğunu düşünür. Kelime, ondan önce söylenenlerin yansıması olmakla birlikte nasıl algılanacağı düşünülerek biçimlendirilen 
bir ögedir (Hunt vd., 2010, s. 70).

Metinlerarasılık, ilk olarak edebi sanat dallarında ön plana çıkarken, bu kavramın sinemayla olan ilişkisi ise daha sonra incelenmeye başlamıştır. Aktulum (2018, s. 19), sinemanın, metinlerarasılık perspektifi üzerinden son yıllarda değerlendirilmeye başlandığını ifade ederek, bu alana yönelik akademik çalışmaların sınırlı sayıda olmasına dikkat çeker. Filmlerin belli oranlarda metinlerarası olduğunu belirten Hayward (2001, s. 201), özgün bir metinden, romandan veya oyundan filmin üretilebileceğini vurgular. Ayrıca yazar, sinemanın, resim ve müzik alanlarından da sıklıkla yararlandığının altını çizer. Sinema, sadece diğer sanat dallarıyla etkileşim hâlinde değildir, bu alanda üretilen filmler birbirleriyle de pek çok açıdan ilişki kurabilirler.

Genette'in yazmış olduğu Palimpsestes (1982) kitabında, bir metnin diğer metinlerle olan ilişkisini kapsayan ötemetinsellik (transtextuality) kavramını önermiştir. Bu bağlamda, Genette, beş tür ötemetinsellik sunmuştur. Bunlar; metinlerarası (intertextuality), yanmetinsellik (paratextuality), üstmetinsellik (metatextuality), önmetinsellik (architextuality) ve anametinsellik (hypertextuality) türleridir (Stam, 2000, s. 207-209). Genette'in çalışmalarından hareketle metinlerarasılık kavramı ve sinema ilişkisinde alt kavramlar tanımlanır. Bunlar; filmlerarasılık, yorumfilmsellik, yanfilmsellik, üstfilmsellik, bellek-filmsellik gibi kavramlardır. Filmlerarasılık; öteki yapıttan alıntılama, aşırma gibi yaklaşımları içerir. Yorumfilmsellik; filmin içinde başka bir yapıtın değerlendirmesinin yapılmasıdır. Yanfilmsellik; film jeneriği ve afişi gibi yan metinlerle izleyicinin söz konusu filmi alımlamasını içermektedir. Üstfilmsellik; pek çok sinema türünün aynı filmde uygulanmasıdır. Bellek-filmsellik; bilindışını temel alarak, yönetmenin farkında olmadan gönderme yapmasını kapsar (Aktulum, 2018, s. 23-24).

Genette'in bu kavrama ilişkin geliştirdiği yaklaşımından yola çıkan Aktulum, iki tür metinlerarası ilişki belirler. Bunlar; ortakbirliktelik ilişkisi ve türev ilişkisidir. Ortakbirliktelik ilişkisi: alıntı, aşırma ve anıştırma; türev ilişkisi ise: parodi (yansılama), pastiş (öykünme) ve alaycı dönüştürümden meydana gelmektedir (2000, s. 93-133). Alıntı, metinlerarasının en belirgin biçimidir ve açık bir şekilde bir metne diğer metinden ekleme yapılır. Aşırma, başkasının metnini kendi metniymiş gibi gösterme ve kullanma durumudur. Anıştırma, okuyucunun/izleyicinin kişisel bilgi birikimi sonunda bulabileceği kavranması zor bir yöntemdir. Parodi, metinlerin anlamını değiştirerek alaycı ve güldürü unsuru olarak eleştirel bir dilin kullanılmasıdır. Berger, parodinin, başka bir metnin bilinçli bir şekilde aktarılmasını sağladığını belirtir (1995, s. 92). Pastiş, eleştirel bir tavırdan ziyade, metni biçimsel açıdan taklit eder. Hayward, pastiş sinemasında remake olarak bilinen yeniden yapım filmlerinin bu tarzı temsil ettiğini vurgular. Ayrıca yazar, parodinin muhalif yapısına dikkat çekerken, pastişin de bu yaklaşımın gölgesinde varlığını sürdürdüğünü öne sürer (2001, s. 277-279). Alaycı dönüştürüm ise, bir yapıtı hem konu hem de biçim yönünden değiştirerek eğlendirici bir metin üretmek olarak bilinmektedir. Hunt ve meslektaşları, metinlerarasılık yaklaşımının, sanatın içinde var olan ve kaçınılması güç bir yapıya sahip olduğunu ifade ederler (Hunt vd., 2010, s. 71). Yazarlara göre, her film kendisinden önce gelenlerin üzerine kurulur. Bu durum özgünlüğü kısıtlamaz, aksine özgürleştirici bir durumu ortaya çıkarır.

Sinema alanında, pek çok filmin metinlerarası kavramına örnek teşkil ettiği söylenebilir. George Lucas, Star Wars filminin ana hikâyesinde Joseph Campbell'ın The Hero With a Thousand Faces (1949) adlı çalışmasından yararlanmıştır. Ayrıca Lucas, Jedi şövalyelerinin kılıçlarla savaşmasını anlatırken Japon yönetmen Akira Kurasowa'nın samuray filmlerine de atıfta bulunmuştur (Kaminski, 
2008 -den akt. Wiggins, 2019, s. 35). Jean-Luc Godard'ın Le Mépris (Nefret, 1963) adlı filminde sinema salonunun tentesindeki başlık vasıtasıyla, bir çiftin ayrılmasını konu alan Viaggio in Italia (Italya'da Yolculuk, Roberto Rossellini, 1954) filmine göndermede bulunur (Stam, 2000, s. 208). De Düva: The Dove (Anthony Lover, George Coe, 1968) filmi, Ingmar Bergman'ın tarzını eğlenceli bir şekilde ele alan parodi olarak bilinmektedir. Söz konusu filmde, Bergman'ın İsveççe konuşan karakterlerine yer verilir. Kiss Me Kate (Öp Beni Kate, George Sidney, 1953) müzikali, Taming of the Shrew (Hırçın Kız, William Shakespeare, 1593) adlı hikâyeden ve West Side Story (Batı Yakası Hikâyesi, Jerome Robbins ve Robert Wise, 1961) müzikali de Romeo and Juliet (Romeo ve Juliet, William Shakespeare, 1594) hikâyesi kaynak alınarak üretilmiştir (Berger, 1995, s. 91-92).

Woody Allen'ın senaryosunu yazdığı Play It Again Sam (Tekrar Çal Sam, Herbert Ross, 1972) adlı filmi, metinlerarası kavramını direkt olarak temsil eden bir yapımdır. Söz konusu film, Casablanca'nın (Kazablanka, Michael Curtiz, 1942) final sahnesini göstererek başlar ve Humphrey Bogart (Jerry Lacy) Allan'a (Woody Allen) sert bir erkek olması yönünde tavsiyeler verir. Play It Again Sam filmi, kült bir yapım olarak kabul edilen Casablanca'ya saygı niteliğinde bir yaklaşım göstererek sinemasal deneyim ile gerçek yaşam arasındaki mesafe üzerine bir ilişki kurar. Woody Allen pek çok filminin hikâyesini, metinlerarasılık kavramı üzerinde biçimlendirir. Nitekim Allen'ın hem yönetip hem de oynadığı Zelig (1983) adlı filminde de Leonard Zelig (Woody Allen) karakteri dış görüntüsünü değiştirebilme yeteneğine sahiptir. Zelig arşiv görüntülerin arasında yer alarak Adolf Hitler'le aynı balkonda yer alır (Hunt vd., 2010, s. 74). Haywad, Tarantino'nun filmlerinde, metinlerarası yaklaşımın sıklıkla yer aldığına dikkat çeker. Tarantino, Pulp Fiction (Ucuz Roman, 1994) filminde kullandığı dekorlar aracılığıyla Edward Hopper'ın resimlerine göndermede bulunurken, söz konusu filmde yer alan Boksör Butch (Bruce Willis), karakter özellikleri açısından Kiss Me Deadly (Öp Beni Öldüresiye, Robert Aldrich, 1955) filmindeki Mike Hammer'a (Ralph Meeker) ve dış görünüş olarak da Nightfall (Jacques Tourneur, 1956) filmindeki oyuncu Aldo Ray'e benzemektedir. Nitekim Tarantino, Godard'ın filmlerine de atıfta bulunduğunu kabul eder (2001, s. 279). Sinemada, teknik açıdan yapılan göndermeler de metinlerarası ilişkinin içinde yer almaktadır. Jules et Jim (Unutulmayan Sevgili, François Truffaut, 1962) filminde, Griffith'in uyguladığı maskeleme yöntemi öne çıkarken, Body Double (Sahte Vücutlar, Brian de Palma, 1984) filmi de öznel açılar ve bakış açısı çekimleri ile Hitchcock'un filmsel anlayışına göndermede bulunur (Stam, 2000, s. 207).

Bilimkurgu filmleri arasında kült bir yapım olarak bilinen Blade Runner, ilk bilimkurgu romanı olarak kabul edilen Frankenstein'ın modern uyarlamasıdır. Mary Shelley'in yazdığı romandaki ana karakter olan Victor Frankestein, başarısız bir deney sonucunda canavar yaratırken, Blade Runner filminde ise Dr. Tyrell karakteri, sonradan kendi yaratıcılarını arayacak olan replikaları yaratmıştır. The Matrix filminde de Alice in Wonderland (Alice Harikalar Diyarında, Lewis Carroll, 1865) The Wonderful Wizard of Oz (Oz Büyücüsü, L. Frank Baum, 1900) romanlarına sözel anıştırmalarda bulunurken, söz konusu filmde Bruce Lee'nin dövüş sanatına da sıkça yapılan göndermeler dikkat çeker (Hunt vd., 2010, s. 80-81). Günden güne sinemayla arasındaki ilişkiyi güçlendiren metinlerarasılık kavramının, pek çok film türünde etkisini göstermesinin yanı sıra özellikle bilimkurgu sinemasında yönetmenler tarafından tercih edilen bir yaklaşım olduğu görülmektedir. 


\section{Brazil Filminin Analizi}

\subsection{Filmin Künyesi}

Yönetmen: Terry Gilliam

Senaryo: Terry Gilliam, Tom Stoppard, Charles McKeown

Yapımcılar: Arnon Milchan, Joseph P. Grace

Oyuncular: Jonathan Pryce, Kim Greist, Michael Palin, Robert De Niro, Katherine Helmond, Bob Hoskins, lan Holm

Görüntü Yönetmeni: Roger Pratt

Kurgu: Julian Doyle

Müzik: Michael Kamen

Yapım Şirketi: Universal Pictures.

\subsection{Filmin Kısa Öyküsü}

Brazil filmi totaliter anlayışla yönetilen distopik bir dünyayı ele almaktadır. Sam Lowry (Jonathan Pryce), devlet memuru olarak çalışan ve yaşadığı bu karanlık alandan sıkılmış bir karakterdir. Bu baskıcı yönetim anlayışından sadece rüyalarında kurtulabilen Sam, burada kendisinden yardım isteyen bir kadını kurtarmaya çalışır. Bir süre sonra, Sam, rüyalarındaki kadın olduğunu düşündüğü Jill Layton'ı (Kim Greist) bulur ve bu iki karakter baskıcı yönetimden gizlenmeye çalışırlar. Fakat bunu başaramazlar, sistem iki karakterin bağımsızlığını ilan etmesine izin vermez ve Layton ölür, Sam de sistemi yönetenler tarafından tutsak edilir.

\subsection{Brazil Filminin Metinlerarasılık Çerçevesinde İncelenmesi}

"8:49 P.M. 20. Yüzyılda bir yerde" şeklinde bir yazıyla başlayan Brazil filminde yönetmen Terry Gilliam, saati açık bir biçimde vurgularken, tarihsel açıdan da belirsizlik yaratmayı tercih eder. Bu bağlamda, filmin kendi içinde çatışmalara sahip olduğunun mesajı izleyiciye verilmektedir. "20. Yüzyılda bir yerde" açıklamasını "dünyanın en muğlak zaman referansı" olarak gösteren Hunt ve meslektaşları (2010, s. 87), filmde kesin olanla belirsizliğin karıştırıldığını ifade ederler. Yazarlar, filmdeki totaliter düzenle gelecek dönemin çağrıştırıldığını, fakat 1930'ların modasının, daktilolardan oluşan bilgisayarların ve kablolu telefonların da geçmişi anımsatarak zamansal bir paradoksun yaratıldığının altını çizerler. Diken ve Laustsen (2011, s. 119), Gilliam'ın Brazil'de, pek çok filme göndermede bulunduğuna dikkat çekerken, söz konusu yönetmenin müzik kullanımının ve zamanı belirsizleştirmesinin de izleyicinin gerçeklikle arasına mesafe koymasını sağladığını belirtirler. Nitekim filme adını veren Brazil şarkısı anlatı yapısında sıklıkla kullanılmaktadır. Filmdeki sahnelerin dramatik yapısına göre şarkının ritmi de değişmektedir.

Brazil filmi, içerdiği konu itibariyle George Orwell'ın Nineteen Eighty-Four adlı romanını akla getirmektedir. Ana karakterler arasındaki bağlantının yanı sıra, iki hikâyede de öne çıkan baskıcı hükümetler benzerlik göstermektedir. Bu hikâyelerde, bireyselliğin toplumsal kimliğe zarar vererek sistem içerisinde bir tehdit unsuru oluşturduğu düşüncesi dikkat çekmektedir. Nitekim filmin yönetmeni Gilliam da Nineteen Eighty-Four romanından esinlendiğini gizlemez (Günal, 2015, s. 49). Brazil filminin distopik türde bir parodi olduğunu belirten Booker (2010, s. 64), söz konusu filmin 
etkili bir hikâyeye sahip olduğunu vurgular. Yazar, bu filmin, bürokrasiye ve monotonluğa bir eleştiri niteliğinde olduğunu ifade ederek, karmaşık bir ironiye sahip olduğunu öne sürer. Buna ek olarak söz konusu filmin, bürokratik sorunları hicvetmesi, Franz Kafka'nın yazdığı Der Prozess (Dava, 1925) romanına bir atıf niteliği taşımaktadır. Arslan (2015), Brazil filminin Kafkaesk ruhtan beslendiğini belirterek, filmde yer alan grotesk karakterleri ve bürokrasi eleştirisini referans olarak gösterir. Yazar, filmdeki iktidarı temsil eden enformasyon bürosunun dev kapısını, Kafka'nın romanından uyarlanan Le Procès'te (Dava, Orson Welles, 1962) yer alan dev mahkeme kapısına benzeterek, Sam Lowry ve Josef K. (Anthony Perkins) karakterlerinin aynı duruma maruz bırakılmalarına dikkat çeker.

Postmodern filmlerde, nostaljik göndermelere sıklıkla rastlanmaktadır. Geçmişe duyulan özlem, geçmiş dönemlerde öne çıkan kült filmlere saygı gösterme gibi pek çok neden bu duruma kaynak niteliği taşımaktadır. Nitekim Brazil'de, devlet görevlilerinin gizli bir biçimde Casablanca filmini izlemeleri geçmişe bir atıf olarak değerlendirilebilir. Hunt ve meslektaşları (2010, s. 74), Casablanca filminin, Sam Lowry ve iş arkadaşlarının totaliter yapı içindeki bürokrasi karşısında özlem duydukları aksiyonu temsil ettiğini ifade ederler. Ayrıca, Sam'in rüyalarında gördüğü kadınla uzaklara uçma hayali de bu film aracılığıyla alaya alınır. Yönetmenin, burada asıl amacının mitolojik bir kahraman olan İkarus'la Sam'i özdeşleştirmek olduğu söylenebilir. İki kahramanın temel hedefi özgürlüğe doğru uçarak baskıcı siyasal anlayıştan kurtulmaktır. İkarus'un hikâyesi kısaca şöyledir: Mimar Daidalos ve oğlu İkarus kral Minos'un emriyle Labyrinthos'a kapatılmışlardır. Daidalos, buradan kaçabilmek için, kendisi ve oğluna birer çift kanat tasarlamış ve balmumuyla yapıştırmıştır. Daidalos, İkarus'a orta seviyede uçması gerektiğini anlatsa da İkarus uçabilmenin mutluluğuyla bu uyarıyı unutmuş ve güneşe doğru iyice yükselmiştir. Doğayı yendiğini ve özgürlüğüne kavuştuğunu düşünen İkarus, güneş tanrısı Helios tarafından cezalandırılır. Kanatlarını tutan balmumunun eritilmesi sonrasında denize düşen İkarus boğularak ölmüştür (Erhat, 1996, s. 153).

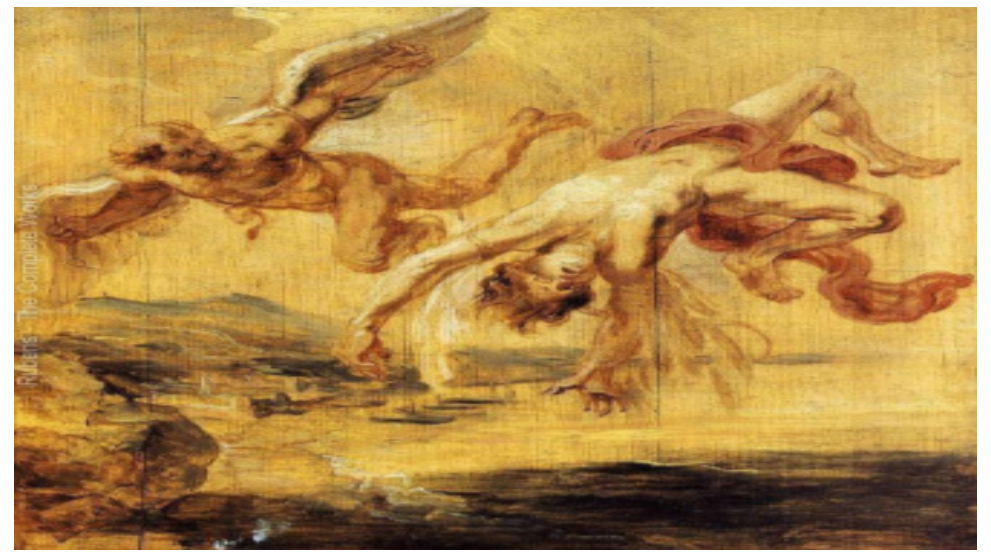

Görsel 1. İkarus'un düşüşünün tasviri - Peter Paul Rubens, 1636 (akt. Yavuz, 2019, s. 537). 


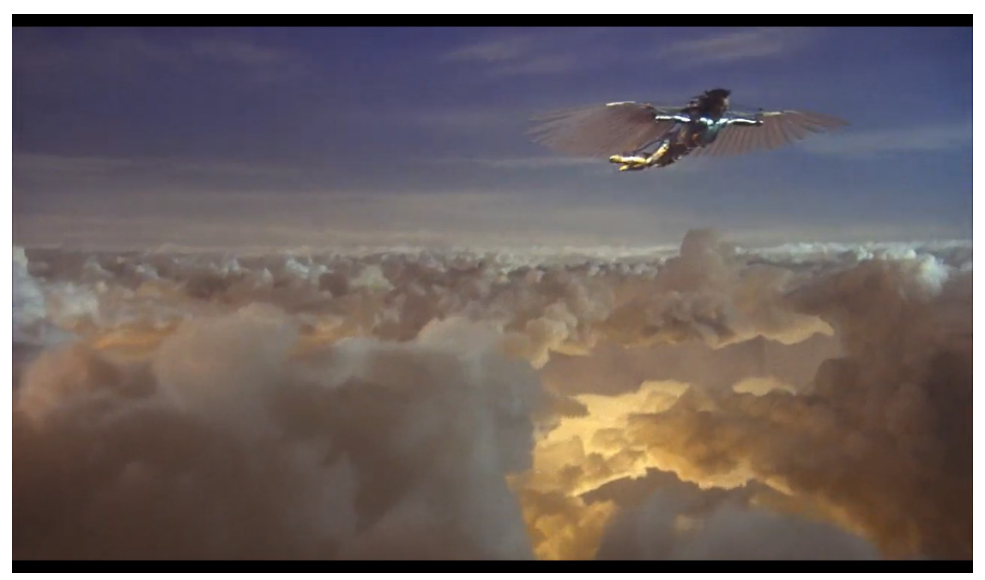

Görsel 2. Sam'in rüyasında uçması

Glass (1986), Sam'in hayallerinin altında anne ve babasıyla çözemediği ilişkilerin yattığını belirtir (akt. Diken ve Laustsen, 2011, s. 136). Söz konusu karakter, Mrs. Terrain'in (Barbara Hicks) ölüm töreni için kiliseye gittiğinde, annesinin (Katherine Helmond) gençleşerek Jill'e dönüştüğünü fark eder. Krajevski de (1988, s. 92), Sam'in İkarus gibi düştükten sonra annesine ve özüne döndüğünü vurgular. Sam'in rüyaları ve annesini Jill'le özdeşleştirmesi Freud'un öne sürdüğü Oedipus kompleksini çağrıştırmaktadır. Bu yaklaşıma göre anneye duyulan arzu ve babayla yaşadığı çatışma sonrasında erkek çocukta iğdiş edilme kaygısı öne çıkar. Bir süre sonra da babasıyla özdeşlemeye başlayan erkek çocuk, fallik evrede yaşadığı sorunları davranışlarına yansıtabilmektedir. Nitekim Sam karakterinin hayalleri de onun bastırılmış dürtülerinin bir sonucu niteliğini taşır. Bu bağlamda filmin bütünü ele alındığında, yönetmenin psikanalitik yaklaşıma göndermede bulunduğu ancak bu konuyu derinlemesine irdelemediği sonucu çıkarılmaktadır.

Gilliam, Brazil filmi aracılığıyla Eisenstein'ın sinemasal yaklaşımına ve bu alanda ürettiği filmlere de sıklıkla atıf yapar. Sinemada özgün bir dil yaratarak, biçimsel anlayışın geliştirilmesinde önemli bir role sahip olan Sovyet yönetmen Sergei Mikhailovich Eisenstein, başta Bronyenosyets Potyomkin (Potemkin Zırhlısı, 1925) olmak üzere ürettiği pek çok filmle sinema tarihinde etkin bir konumda yer alır. Cowen (1998), Brazil filmindeki muhafızları, Bronyenosyets Potyomkin'deki Kazak askerlere benzetir (akt. Diken ve Laustsen, 2011, s. 136). Odessa Merdivenleri sekansı, Bronyenosyets Potyomkin filmine dair en çok iz bırakan bölümdür. Sayısız filmde bu sekansa atıf yapılmıştır. Nitekim, Brazil filminde de temizlikçi kadının vurularak yer cilalama makinesini elinden kaçırması Bronyenosyets Potyomkin'deki bebek arabasının merdivenden aşağıya yuvarlanmasına yapılan ironik bir göndermedir.

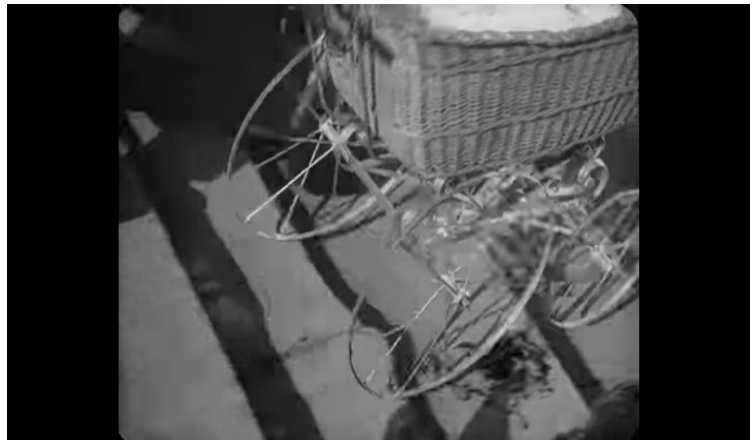

Görsel 3. Bronyenosyets Potyomkin'deki bebek arabasının merdivenden aşağıya yuvarlandığı sahne

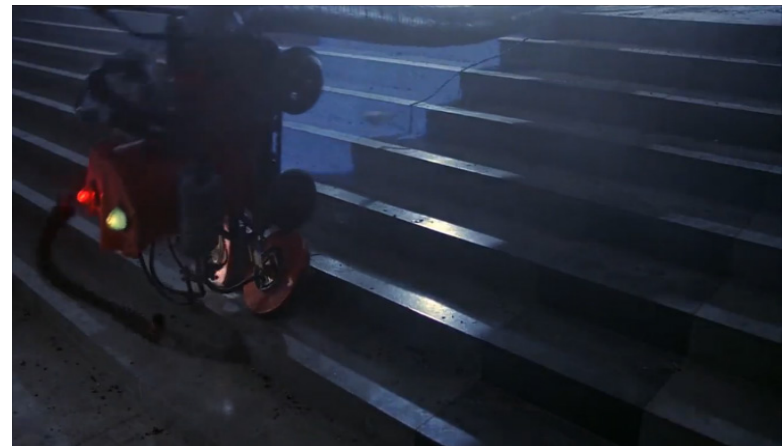

Görsel 4. Brazil filminde, yer cilalama makinesinin merdivenden aşağıya düştüğü sahne 
Brazil'dekitemizlikçi kadın (Bkz. Görsel 6), Bronyenosyets Potyomkin'degözünden vurulan karakterin (Bkz. Görsel 5) taklidi niteliğindedir. Hunt ve meslektaşları, söz konusu göndermeler için ikonik montaj tanımlaması yaparlar. Yazarlar, bu durumu, bir yönetmenin diğerine saygılı bir şekilde şapka çıkarması ve sinema tarihini bile izleyicilere de göz kırpmak olarak açıklamaktadırlar (2010, s. 78). Gilliam'ın, Eisenstein'ın Oktyabr (Ekim, 1927) filmine de atıfta bulunduğunu ifade eden Krajewski, Brazil'de devlet adına insanlara işkence yapan Jack Lint (Michael Palin) karakterinin giydiği maskeyi referans olarak gösterir. Yazar, Oktyabr filmindeki "tanrının maskeleri" montajından esinlenildiğini öne sürer (1988, s. 96).

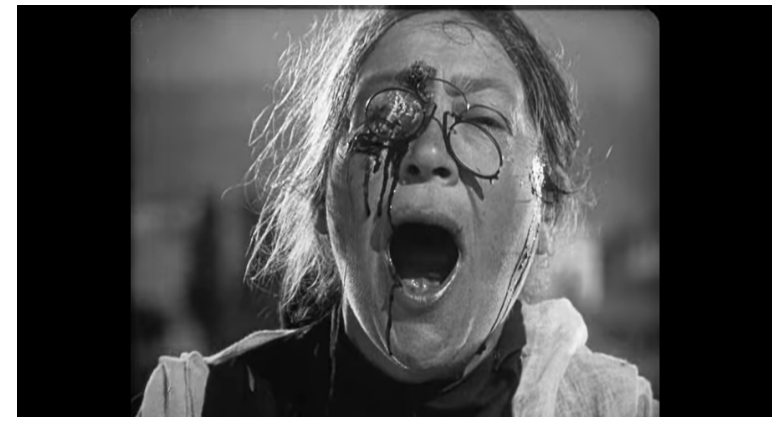

Görsel 4. Bronyenosyets Potyomkin' filminden bir sahne

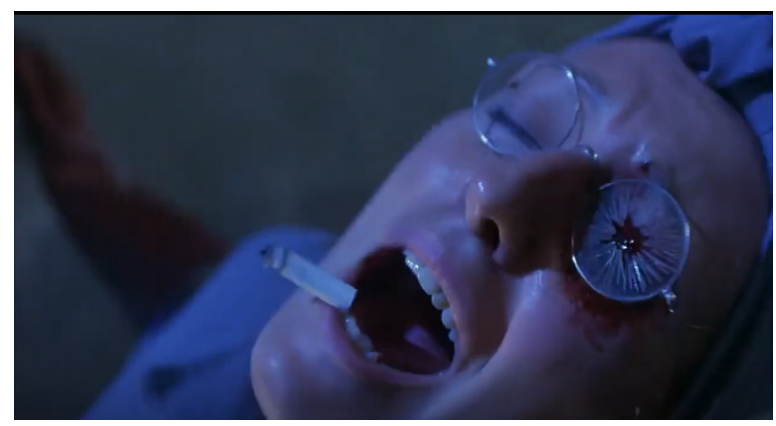

Görsel 5. Brazil filminden bir sahne

Brazil filminin final bölümünde, Harry Tuttle (Robert De Niro) ve arkadaşlarının duvardan iple inerek Sam'i kurtarmaları, James Bond serilerini akla getirmektedir. Bunun yanı sıra, Sam'e yapılan işkence One Flew Over the Cuckoo's Nest (Guguk Kuşu, Milos Forman, 1975) filmini çağrıştırmaktadır (Hunt vd., 2010, s. 79). Brazil'i "tuhaf bir komedi" olarak tanımlayan Diken ve Laustsen, filmin abartılı bir tarzı benimsemiş olmasını Monty Python's Flying Circus (Monty Python'un Uçan Sirki, Graham Chapman, Eric Idle ve Terry Jones, 1969-1974) adlı televizyon dizisini hatırlattığını belirtirler (2011, s. 119). Ayrıca, Jill'in Sam'i aracından atmaya çalışması ve Sam'in araçtan düşmeme çabası da Raiders of the Lost Ark (Kutsal Hazine Avcıları, Steven Spielberg, 1981) filminin kovalamaca sahnelerini çağrıştırır (Krajevski, 1988, s. 95). À nous la liberté (Özgürlük Bizimdir, René Clair, 1931) filminde, fabrikada iletişim kurmak için kullanılan borular ve Modern Times (Modern Zamanlar, Charles Chaplin, 1936) filminde işini ihmal eden işçilerini ekran üzerinden takip eden müdürün sahneleri, Brazil'de yeniden canlandırılır (Arslan, 2015). Brazil filmindeki devlet yapısının Nazi Almanya'sını akla getirdiğini belirten Gediz (2020), filmdeki muhafızların Adolf Hitler zamanında kurulan SS (Schutzstaffel) birliklerinin üniformalarından giydiklerini vurgular. Kayıt dairesi binasındaki heykelin üzerinde yazan “THE TRUTH SHALL MAKE YOU FREE” (Gerçek sizi özgür kılacak) yazısının Auschwitz-Birkenau toplama kampının girişinde yazan "Arbeit macht frei” (Çalışma insanı özgürleştirir) sözüne gönderme olarak nitelendirilmesinin yanı sıra İncil'in King James versiyonunda yer alan bir ayeti de (And ye shall know the truth, and the truth shall make you free - Gerçeği bileceksiniz ve gerçek sizi özgür kılacak) anıştırdığı söylenebilir.

\section{Sonuc}

Postmodernizmin, sinema sanatında etkisini göstermesiyle birlikte, metinlerarası yöntemin de bu sanat dalında belirgin bir biçimde tercih edildiği görülmektedir. Sinemanın, diğer sanat dallarıyla etkileşim sağlamasının yanı sıra, bu alanda çekilen filmlerin de birbirini etkilediği ve böylelikle metinlerarası ilişkinin kurulduğu sonucuna ulaşılmaktadır. Nitekim bilimkurgu filmlerinde de bu yaklaşıma ilişkin pek çok örnek çalışmada ele alınmıştır. Özellikle kült yapımlar olarak kabul 
edilen; Star Wars, Blade Runner, Metropolis, Star Trek gibi filmlerin bilimkurgu türünde öne çıktı̆̆ı görülürken, sinema alanında bu filmlere yapılan göndermelerin de oldukça fazla olduğu söylenebilir.

Çalışmada incelenen Brazil'in, bilimkurgu sinemasında dikkat çeken filmlerden biri olduğu bilinmektedir. Filmin, totaliter sisteme bir eleştiri niteliğinde olduğu gözlenirken, bu yaklaşımı da Sam karakteri üzerinden yansıttığı anlaşılmaktadır. Fakat söz konusu filmde, doğrudan bir sistem eleştirisinin bulunmadığı, daha çok ironik göndermelerin tercih edildiği söylenebilir. Nitekim filmin son bölümünde, Sam'in Tuttle tarafından kurtarılacağı izlenimi yaratılmış, sonrasında da bu durumun onun hayal dünyasında gerçekleştiği ve söz konusu karakterin esaretten kurtulamadığı dikkat çekmiştir. Bu bağlamda yönetmen, filmin anlatı yapısını Sam üzerinden ele almış olup, totaliter anlayışın getirdiği sorunları da bu karakterin yaşadığı olaylarla izleyiciye göstermeyi tercih etmiştir.

Distopik bir atmosfere sahip olan bu filmde, zengin-fakir ayrımının belirgin bir biçimde öne çıkarken, teknolojinin insan yaşamına ve bedenine hükmederek onu yönettiği vurgusu dikkat çekmektedir. Brazil şarkısıyla başlayan filmde, zaman belirsizliği dikkat çekerken, yaratılan teknolojik araçların da bu belirsizliği yansıttığı görülmektedir. George Orwell'ın Nineteen Eighty-Four adlı romanını çağrıştıran filmde hem ana karakterlerin benzerliği hem de baskıcı yönetim anlayışları bu çıkarımın yapılmasını mümkün kılmışıı. Ayrıca, bu çalışma kapsamında yapılan incelemede, Brazil filminin Kafka'nın romanlarında yarattığı ögelerden (grotesk karakterler, bürokratik sorunlar) etkilendiği sonucuna ulaşılmıştır.

Postmodern yaklaşımda, nostaljik unsurların öne çıktığı bilinirken, bu anlayışı temsil eden filmlerde de söz konusu durumun ele alındığı görülmektedir. Nitekim metinlerarası yöntemin filmler arasındaki etkileşimi temsil ettiği ve bu çerçevede çeşitli kavramlar geliştirdiği söylenebilir. Metinlerarası yaklaşım üzerinden incelenen Brazil filminde, söz konusu nostaljik göndermelerin anlamı güçlendirerek dramatik yapıya katkı sağladığı ifade edilebilir. Casablanca, Bronyenosyets Potyomkin, Oktyabr, Le Procès, One Flew Over the Cuckoo's Nest, Monty Python's Flying Circus, Raiders of the Lost Ark, À nous la liberté, Modern Times gibi önemli yapımlar, Brazil filminde çeşitli anlatı unsurlarıyla ele alınmıştır. Bu göndermelerden bazıları (Bronyenosyets Potyomkin, Casablanca) açık bir biçimde izleyiciye sunulurken, bazıları da (Oktyabr, À nous la liberté) izleyicinin entelektüel bilgi birikimiyle fark edebileceği anıştırmalar olarak dikkat çekmiştir.

Yapılan incelemede, bilimkurgu sinemasında metinlerarası ilişkileri temsil eden unsurların yer aldığı görülürken, Brazil filminin de bu unsurlara, anlatı yapısında yer verdiği sonucu çıkarılmaktadır. Distopik bir evrende geçen bu filmin, bilimkurgu türünün özelliklerini yansıttığı aynı zamanda metinlerarası etkileşimi de temsil ettiği anlaşılmaktadır. Yönetmenin, filmin anlatı yapısında (zaman, mekân, karakterler, olaylar dizisi ve neden-sonuç) metinlerarası yöntemi referans aldığı ve aynı zamanda biçimsel tercihleriyle de bu etkileşimi güçlendirdiği görülmektedir. 


\section{Kaynakça}

Abisel, Nilgün (1995). Popüler Sinema ve Türler. İstanbul: Alan Yayıncılık.

Abrams, M. H. (1999). A Glossary of Literary Terms. United States of America: Heinle \& Heinle.

Aktulum, Kubilay (2000). Metinlerarası İlişkiler. Ankara: Öteki Yayınevi.

Aktulum, Kubilay (2018). Sinema ve Metinlerarasılık: Filmlerarası Etkileşimler ve Aktarımlar. Ankara: Çizgi Yayınevi. Allen, Graham (2000). Intertextuality. Londra \& New York: Routledge.

Barthes, Roland (1993). Göstergebilimsel Serüven. (Çev. Mehmet Rifat, Sema Rifat). İstanbul: Yapı Kredi Yayınları.

Baudou, J. (2005). Bilimkurgu. (Çev. İpek Bülbüloğlu). Ankara: Dost Kitabevi Yayınları.

Berger, A. A. (1995). Cultural Critism: A Primer of Key Concepts. California: Sage Publications.

Booker, M. K. (1994). The Dystopian Impulse in Modern Literature: Fiction as Social Criticism. Londra: Greenword Press.

Booker, M. K. (2010). Historical Dictionary of Science Fiction Cinema. Plymouth: Scarecrow Press.

Bordwell D. \& Thompson K. (2008). Film Art: An Introduction. New York: McGraw-Hili Companies.

Büyükdüvenci S. \& Öztürk S. R. (2014). Postmodernizm ve Sinema. Sabriye Büyükdüvenci \& Semire Ruken Öztürk (Der.). Postmodernizm ve Sinema. (s.13- 36) içinde. Ankara: Dipnot Yayınları.

Claeys, Gregory (2011). The Origins of Dystopia: Wells, Huxley and Orwell. Gregory Claeys (Ed.) The Cambridge Companion to Utopian Literature. (s.107-131) içinde. New York: Cambridge University Press.

Cornea, C. (2007). Science Fiction Cinema: Between Fantasy and Reality. Edinburgh: Edinburgh University Press.

Curtis, C. P. (2010). Postapocalyptic Fiction and Social Contract: "We'll Not Go Home Again". UK: Rowman \& Littlefield Publishers.

Diken, B. \& Laustsen, C. B. (2011). Filmlerle Sosyoloji. İstanbul: Metis Yayınları.

Erhat, Azra (1996). Mitoloji Sözlügü. İstanbul: Remzi Kitabevi.

Günal, H. (2015). Distopik Filmler Üzerinden Mekansal Okumalar. (Yayınlanmamış Yüksek Lisans Tezi) İstanbul Teknik Üniversitesi Fen Bilimleri Enstitüsü, İstanbul.

Hayward, S. (2001). Cinema Studies: The Key Concepts. London and New York: Routledge.

Hunt R. E., Marland J. \& Rawle S. (2010). The Language of Film. Lausanne: AVA Publishing.

Hutcheon, Linda (1998). A Poetics of Postmodernism: History, Theory, Fiction. New York and London: Routledge.

Jameson, Fredric (1997). Postmodernism, or the Cultural Logic of Late Capitalism. United States of America: Duke University Press.

Krajewski, Bruce. (1988). Post-Modernism, Allegory, and Hermeneutics in Brazil. lowa Journal of Literary Studies, 9(1), 83-101. https://doi.org/10.17077/0743-2747.1276.

Ott, B. \& Walter, C. (2000). Intertextuality: Interpretive Practice And Textual Strategy. Critical Studies in Media Communication, 17(4), 429-446. https://doi.org/10.1080/15295030009388412.

Patton, M. (1990). Qualitative Evaluation and Research Methods. CA: Sage Publications.

Roloff, B. \& SeeBlen, G. (1995). Ütopik Sinema: Bilimkurgu Sinemasının Tarihi ve Mitolojisi. (Çev. Veysel Atayman). 
İstanbul: Alan Yayıncılık.

Stam, Robert (2000). Film Theory An Introduction. USA and UK: Blackwell Publishers.

Vieira, Fatima (2011), The Concept of Utopia. Gregory Claeys (Ed.) The Cambridge Companion to Utopian Literature. (s.3-27) içinde. New York: Cambridge University Press.

Wiggins, Bradley E. (2019). The Discursive Power of Memes in Digital Culture: Ideology, Semiotics and Intertextuality. New York and London: Routledge.

Yavuz, Nuri (2019). Resim Sanatında İkarus Miti. Avrasya Sosyal ve Ekonomi Araştırmaları Dergisi, 6 (3), 534-542.

Yıldııım A. \& Şimşek H. (2018). Sosyal Bilimlerde Nitel Araştırma Yöntemleri. Ankara: Seçkin Yayıncılık.

\section{İnternet Kaynakları}

Arslan, Rafet (2015). Düş Gücü İle Alternatif Bir Dünya Yaratan Film: Brazil. https://www.bilimkurgukulubu.com/ sinema/dus-gucu-ile-alternatif-bir-dunya-yaratan-film-brazil/ adresinden 10.12 .2020 tarihinde erişilmiştir.

Gediz, U. G. (2020). Bin Dokuz Yüz Seksen Dört “Buçuk”: Brazil (Terry Gilliam, 1985). https://medium.com/degisenbakis/ brazil-film-incelemesi-9a7659a36c03 adresinden 03.01.2021 tarihinde erişilmiştir.

\section{Metinde Adı Geçen Filmler}

Aldrich, Robert (Yapımcı), \& Aldrich, Robert (Yönetmen). (1955). Kiss Me Deadly [Sinema Filmi]. U.S.A.: Parklane Pictures.

Beauregard G., Ponti C. (Yapımcı), \& Godard, J. L. (Yönetmen). (1963). Le Mépris [Sinema Filmi]. France: Les Films Concordia.

Bender, L. (Yapımcı), \& Tarantino, Q. (Yönetmen). (1994). Pulp fiction [Sinema Filmi]. U.S.A.: Miramax.

Berbert M., Truffaut F. (Yapımcı), \& Truffaut F. (Yönetmen). (1962). Jules et Jim [Sinema Filmi]. France: Les Films du Carrosse/SEDIF.

Blyoh, Y. (Yapımcı), \& Eisenstein, S. (Yönetmen). (1925). Bronyenosyets Potyomkin [Sinema Filmi]. Rusya: Goskino.

Canton N., Gale B. (Yapımcı), \& Zemeckis, R. (Yönetmen). (1985). Back to the Future [Sinema Filmi]. U.S.A.: Universal Pictures.

Chaplin, Charles (Yapımcı), \& Chaplin, Charles (Yönetmen). (1936). Modern Times [Sinema Filmi] U.S.A.: United Artists. Clifford, Frank (Yapımcı), \& Clair, René (Yönetmen). (1931). À nous la liberté [Sinema Filmi]. France: Films Sonores Tobis.

Coe, G. (Yapımcı), \& Coe, G. (Yönetmen). (1968). De Düva: The Dove [Sinema Filmi]. U.S.A.: Schoenfeld Films. Coppola F. F. \& Lucas, George (Yönetmen). (1971). THX 1138 [Sinema Filmi]. U.S.A.: Warner Bros.

Cummings, Jack (Yapımcı), \& Sidney, G. (Yönetmen). (1953). Kiss Me Kate [Sinema Filmi]. U.S.A.: Metro-GoldwynMayer.

Deeley, M. (Yapımcı), \& Scott, R. (Yönetmen). (1982). Blade Runner [Sinema Filmi]. U.S.A.: Warner Bros.

Greenhut, R. (Yapımcı), \& Allen, Woody (Yönetmen). (1983). Zelig [Sinema Filmi]. U.S.A.: Warner Bros.

Hurd, G. A. (Yapımcı), \& Cameron, J. (Yönetmen). (1984). The Terminator [Sinema Filmi]. U.S.A.: Orion Pictures. Ivanoff, K. (Yapımcı), \& Gance, A. (Yönetmen). (1931). La fin du monde [Sinema Filmi]. France: With L'Écran d'Art Jacobs, A. (Yapımcı), \& Ross, Herbert (Yönetmen). (1972). Play It Again Sam [Sinema Filmi]. U.S.A.: Paramount 


\section{Pictures.}

Kubrick, Stanley (Yapımcı), \& Kubrick, Stanley (Yönetmen). (1971). A Clockwork Orange [Sinema Filmi]. U.S.A.: Warner Bros.

Kubrick, S., Spielberg S. (Yapımcı), \& Spielberg, S. (Yönetmen). (2001). A.I. Artificial Intelligence [Sinema Filmi]. U.S.A.: Warner Bros.

Linder George, Zinnemann Tim (Yapımcı), \& Glaser, Paul Michael (Yönetmen). (1987). Running Man [Sinema Filmi]. U.S.A.: Braveworld Productions, Taft Entertainment.

Lucas, G. (Yapımcı), \& Lucas, G. (Yönetmen). (1977). Star Wars [Sinema Filmi]. U.S.A.: Lucas Films.

Marshall, F. (Yapımcı), \& Spielberg, S. (Yönetmen). (1981). Raiders of the Lost Ark [Sinema Filmi]. U.S.A.: Paramount Pictures.

Meinert R., Pommer E. (Yapımcı), \& Wiene, R. (Yönetmen). (1920). Das Cabinet des Dr. Caligari [Sinema Filmi]. Germany: Decla-Bioscop.

Méliès, Georges (Yapımcı), \& Méliès, Georges (Yönetmen). (1902). Le Voyage dans la lune [Sinema Filmi]. France: Star Film Company.

Michelin, Andre (Yapımcı), \& Godard, J. L. (Yönetmen). (1965). Alphaville [Sinema Filmi]. France: Athos Films.

Milchan A., Grace P. J. (Yapımcı), \& Gilliam, T. (Yönetmen). (1985). Brazil [Sinema Filmi]. U.S.A.: Universal Pictures.

Palma, D. B. (Yapımcı), \& Palma, D. B. (Yönetmen). (1984). Body Double [Sinema Filmi]. U.S.A.: Columbia Pictures.

Parkes W., Laurie, M. (Yapımcı), \& Sonnenfeld, B. (Yönetmen). (1997). Men in Black [Sinema Filmi]. U.S.A.: Columbia Pictures.

Phillips J., Phillips M. (Yapımcı), \& Spielberg, S. (Yönetmen). (1977). Close Encounters of the Third Kind [Sinema Filmi]. U.S.A.: Columbia Pictures.

Pommer, E. (Yapımcı), \& Lang, Fritz (Yönetmen). (1927). Metropolis [Sinema Filmi]. Germany: UFA

Richmond, Ted (Yapımcı), \& Tourneur, J. (Yönetmen). (1956). Nightfall [Sinema Filmi]. U.S.A.: Columbia Pictures.

Rossellini, R. (Yapımcı), \& Rossellini, R. (Yönetmen). (1954). Viaggio in Italia [Sinema Filmi]. Italy.

Salkind, A. (Yapımcı), \& Welles, Orson (Yönetmen). (1962). Le Procès [Sinema Filmi]. France, Italy, Germany: ParisEuropa Productions, Hisa-Film, Finanziaria Cinematografica Italiana

Silver, J. (Yapımcı), \& Wachowski Brothers (Yönetmen). (1999). The Matrix [Sinema Filmi]. U.S.A.: Warner Bros.

Sergeev, V. (Yapımcı), \& Eisenstein, S. (Yönetmen). (1927). Oktyabr [Sinema Filmi]. Rusya: Sovkino.

Wallis, H. B. (Yapımcı), \& Curtiz, M. (Yönetmen). (1942). Casablanca [Sinema Filmi]. U.S.A.: Warner Bros.

Wilson, Daniel (Yapımcı), \& Schlöndorff, Volker (Yönetmen). (1990). The Handmaid's Tale [Sinema Filmi]. U.S.A., Germany: Bioskop Film, Cinecom Entertainment Group, Cinétudes Films.

Wise, R. (Yapımcı), \& Wise R., Robbins J. (Yönetmen). (1961). West Side Story [Sinema Filmi]. U.S.A.: United Artists. Zaentz S., Douglas M. (Yapımcı), \& Forman, M. (Yönetmen). (1975). One Flew Over the Cuckoo's Nest [Sinema Filmi]. U.S.A.: Fantasy Films.

Zanuck R., Brown D. (Yapımcı), \& Spielberg, S. (Yönetmen). (1975). Jaws [Sinema Filmi]. U.S.A.: Universal Pictures. 


\section{Extended Abstract}

\section{Purpose of Research}

In this study, it is aimed to analyze the film of Brazil in detail by examining the development of science fiction genre in cinema, based on its relationship with the concept of intertextuality.

\section{Research Questions}

Theoretically, the concept of intertextuality, introduced by Julia Kristeva in the 1960s, handles with the interaction between texts. This approach, which is widely preferred in postmodern texts, first came to the fore in literary art branches, and later established a relationship with cinema. As a matter of fact, the relationship between the concept of intertextuality and cinema was examined in detail within the scope of the study, and supported with examples from various films. In this context, the factors representing the intertextual interaction in science fiction cinema, which is the basis of the study, were examined in the context of cult films representing this genre.

\section{Literature Review}

Science fiction, known as a popular genre in cinema, enables the creation of a fictional universe by establishing a relationship between reality and imagined. In this universe where technological developments come to the fore, many issues such as alien invaders, nuclear wars, robots and artificial intelligence are discussed. George Méliès's film Le Voyage dans la lune is considered to be the first science fiction film in the history of cinema. The science fiction genre, which has been developing since the early stages of cinema, has established relationships with many art movements. As a matter of fact, it was released in the 1920s; Das Cabinet des Dr. Caligari and Metropolis films, the expressionism movement is seen to be effective. Today, especially the postmodernism movement has interacted with many genres, especially science fiction, by showing its effect in the field of cinema. It is known that postmodernism, whose relationship with cinema started after the 1980s, integrated various approaches (deconstruction, intertextuality, irony, parody, pastiche) with cinema. Among these approaches, intertextuality is clearly preferred in science fiction films. This approach, which examines the relationship between texts, provides the creation of an original science fiction language.

\section{Methodology}

In this study, phenomenology design, one of the qualitative analysis methods, was preferred. Indicating the science fiction genre, Brazil's relationship with many films and branches of art created the structure of the study. In this framework, purposive sampling method was used, considering that it was suitable for the purpose of the study.

\section{Results and Conclusion}

The story of the film Brazil, which criticizes the totalitarian management system through the character of Sam, takes place in a dystopian universe. In this film, which reflects the chaotic order in the social structure, there are many elements that evoke the intertextual method. This film, named after the 
song Brazil, takes place in an uncertain time frame. The oppressive management approach and the characteristics of the main character in the film Brazil bring to mind George Orwell's novel Nineteen Eighty-Four. Indeed, the director of the film, Terry Gilliam, does not hide that it is inspired by Orwell's novel. In addition, the factors created in Brazil using the novels of Franz Kafka attract attention. The grotesque characters, giant doors and bureaucratic problems in the film refer to elements in Kafka's stories.

Cult films that have influenced the history of cinema such as Casablanca, Bronyenosyets Potyomkin, Oktyabr, One Flew Over the Cuckoo's Nest, Raiders of the Lost Ark, À nous la liberté, Modern Times, have been handled in Brazil with various narrative factors. In this context, it is seen that the references to the film Bronyenosyets Potyomkin, directed by Sergei Mikhailovich Eisenstein, stand out prominently, while the scenes of the floor polishing machine rolling down the stairs and the cleaning woman's eyeglass cracked are the scenes that draw the most attention among these references.

In Brazil, some of the references to other films (Bronyenosyets Potyomkin, Casablanca) were openly presented to the audience, while some (Oktyabr, À nous la liberté) attracted attention as allusions that the audience can recognize with their intellectual knowledge. Another prominent interaction in the film is the resemblance of Icarus and Sam. Icarus, a mythological character, while flying towards freedom with his wings, was punished by the sun god and was thrown into the sea. While Sam's flying like Icarus in his dreams indicates a visual inspiration, the ascension phase of this character in his business life evokes the rise of Icarus to the sky after the emotions he experienced while flying. Also, the sharp decline of both characters after their rise is an indication that they have similar endings.

As a result, intertextual interaction was used in science fiction cinema, while it was observed that cult films, literary works, mythological heroes, factors that evoke religious and political issues were found in Brazil, which was examined within the scope of the study. 